\title{
Amino Acid Substitutions in Growth Hormone and Growth Hormone Receptor Genes Mutants in Camelus dromedarius
}

\author{
Sajida Sabahat ${ }^{1}$, Asif Nadeem ${ }^{1, *}$, Maryam Javed ${ }^{1}$, Muhammad Yasir Zahoor ${ }^{1}$, \\ Shahid Nabeel ${ }^{1}$ and Abu Saeed Hashmi ${ }^{2}$ \\ ${ }^{1}$ Institute of Biochemistry and Biotechnology, University of Veterinary and Animal \\ Sciences, Sheikh Abdul Qadir Jellani Road, Lahore, Pakistan. \\ ${ }^{2}$ Camel Breeding and Research Station, Rakhmani, Bhakkar, Pakistan.
}

\begin{abstract}
A B S T RA C T
The identification of genetic polymorphisms in genes enable us to estimate biological similarities and obtain a better perspective of quantitative traits that play key roles in development and regulating growth. The present study was conducted to characterize genetic variability in the growth hormone (GH) and growth hormone receptor (GHR) of Camelus dromedarius. GH is secreted and synthesized from somatotroph cells of the anterior pituitary lobe and plays significant role in growth, development, metabolism, lactation, and reproduction. Growth hormone interact with GHRs and influence on metabolism and growth. Changes in GHR concentration affect signalling pathways, binding capacity and alters activity of GH. Therefore, the GH and GHR genes are considered important candidate genes. DNA samples of Marecha camel were collected from the Camel Breeding and Research Station at Rakhmani Bhakar, Pakistan. Two significant polymorphic sites were identified in GH gene and three in GHR gene. Out of these, T1720A polymorphism in GH and A211927G polymorphism in GHR genes changed the amino acid from leucine to histidine and methionine to valine, respectively. These polymorphic results suggest that Marecha camel, a major breed in Pakistan, has genetic variability in the GH and GHR genes. These results suggest that Marecha camel has genetic variability in growth-related genes and identified

polymorphisms may be helpful for association studies and future selection programs.
\end{abstract}

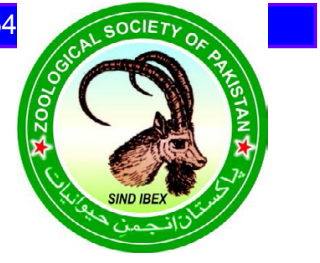

CrossMark

\begin{tabular}{l} 
Article Information \\
Received 21 February 2019 \\
Revised 12 April 2019 \\
Accepted 03 May 2019 \\
Available online 03 October 2019 \\
Authors' Contribution \\
\hline AN designed the study. SS carried \\
out the genomic work. SH collected \\
the samples. SS, AN, MJ and MYZ, \\
analyzed the data and wrote the \\
manuscript. AN and ASH revised the \\
manuscript. \\
Key words \\
Polymorphism, GH gene, GHR \\
gene, growth, Marecha, Camelus \\
dromedarius
\end{tabular}

\section{INTRODUCTION}

$\mathrm{P}_{\mathrm{c}}$ akistan ranks eighth among the main camel-raising countries of the world (Faye, 2015). The camel population is approximately 1.2 million in Pakistan (Economic Survey, 2016-17) representing 22\% of total livestock production. Nowadays, research interest on genetic polymorphisms of candidate genes has increased due to their utilization in genetic selection, as well as being helpful to differentiate evolutionary relationships among different livestock breeds (Sodhi et al., 2007). Association of single nucleotide polymorphisms (SNPs) with economically important traits has been commonly used as a selection tool in various other livestock species such as cattle (Ge et al., 2003), sheep (Bastos et al., 2001) and goats (Gupta et al., 2007). Various candidate genes associated with different growth traits are mainly present on the growth hormone axis. Growth hormone $(\mathrm{GH})$ is a polypeptide hormone and has various biological actions including

\footnotetext{
* Corresponding author: asifnadeem@uvas.edu.pk 0030-9923/2020/0049-0001 \$ 9.00/0

Copyright 2020 Zoological Society of Pakistan
}

somatogenic, lactogenic, diabetogenic and insulin-like effects (Ishag et al., 2010). GH is considered the primary regulator in metabolism and postnatal growth that has effects on health, growth rate, milk production, body composition and aging by controlling expression of many genes (Lincoln et al., 1995; Sumantran et al., 1992). The growth hormone receptor (GHR) facilitates the biological function of $\mathrm{GH}$ by stimulating myogenic signals and influences transcription of many genes (Argetsinger et al., 1996). GHR mediates its effect by signal transduction of the target cells. Allelic variations in GHR affects its signalling pathways and binding capacity. Mutation in the GHR gene causes short stature and Laron syndrome in human. GHR gene has nine untranslated exons and encoded by BTA2 0 in cattle. The binding capacity of GH associated with polymorphisms of GHR is considered as the candidate gene which influences development, growth and carcass traits in livestock animals (Blair et al., 2002). The camel GH gene is about 1900 bp in length and is comprised of five exons and four introns (Maniou et al., 2001 ). It is a $22 \mathrm{kDa}$ single chain polypeptide and secreted in a circadian and pulsatile manner by somatotrophs of the anterior pituitary gland (Dybus, 2002). GH and GHR genes 
are considered important candidate genes for growth, milk and carcass traits in livestock. This study attempted to identify polymorphisms in GH and GHR genes which may be used for association of polymorphisms with growth traits in the Marecha camel population, leading to marker assisted selection for future camel breeding plans.

\section{MATERIAL AND METHODS}

Selection of animals and blood samples

The blood samples $(n=105)$ of Marecha camels were collected from the Camel Breeding and Research Station (CBRS) at Rakhmahni Bhakkar, Pakistan. Blood samples $(10 \mathrm{~mL})$ were collected aseptically from the jugular vein of animals into falcon tubes containing $0.5 \mathrm{M}$ ethylenediamine tetra-acetic acid (EDTA) as an anticoagulant.
DNA extraction and quantification

DNA was isolated from white blood cells (WBCs) suspended in the preserved samples using a standard phenol-chloroform-isoamyl alcohol DNA extraction protocol (Sambrook et al., 2001). The quantity and quality of every DNA sample was evaluated using a gel electrophoresis ( $0.8 \%$ agarose gel) and NanoDrop ND1000 spectrophotometer (Nano DropTechnologies). All samples were brought to the same concentration level, namely $50 \mathrm{ng} / \mu \mathrm{L}$.

\section{Designing of primers}

Three primers for GH genes and nine for GHR were designed by using Primer3 software (http://frodo.wi.mit. edu/) from NCBI database (GenBank accession number GH: AJ575419 and GHR: 105097468) to amplify 15 exon regions. Primer sequences were optimized using OligoTM primer design software (Table 1).

Table I. List of primers for amplification of growth hormone (GH) and growth hormone receptor (GHR) genes.

\begin{tabular}{llllll}
\hline Primer Name & Sequence & Length & GC content & Tm & Product Length \\
\hline GHF1 & AAAATAAGTGGGGGCAGAGG & 20 & 50 & 60.31 & 187 \\
GHR1 & TCACCCTTCCGTACACATCA & 20 & 50 & 59.96 & ---- \\
GHF2 & CTTCTGAATGTGAGCGTGGA & 20 & 50 & 59.98 & 839 \\
GHR2 & TTGGAAAAGAGCAAGGAGGA & 20 & 45 & 59.93 & ---- \\
GHF3 & GTGGAGGGGAAGAGAAGGAG & 20 & 60 & 60.19 & 716 \\
GHR3 & CTGGGGAGGGGTAACAGATT & 20 & 55 & 60.18 & ---- \\
GHRF1 & ATTTGCCATGAGGTGGTTCT & 20 & 45 & 59.41 & $493 \mathrm{bp}$ \\
GHRR1 & TCGGCTGCTACTTGGAACTT & 20 & 50 & 60.02 & ---- \\
GHRF2 & CCAGAAGGTTTCCATTTGCT & 20 & 45 & 59.17 & $396 \mathrm{bp}$ \\
GHRR2 & CAATTTCGGTCAGTCATCCA & 20 & 45 & 59.50 & ---- \\
GHRF3 & GAAGCTGTGACCCAGGAAAA & 20 & 50 & 60.23 & $439 \mathrm{bp}$ \\
GHRR3 & GCCAGATCTCCAGTGCCTAA & 20 & 55 & 60.36 & ---- \\
GHRF4 & TAGCCTCCTATTGGTCTGC & 19 & 52 & 55.48 & $500 \mathrm{bp}$ \\
GHRR4 & ACCTCCATCCACCTACAGA & 19 & 52 & 55.30 & ---- \\
GHRF5 & CAGAAGAAACCACTCCGTCAG & 21 & 52 & 59.89 & $439 \mathrm{bp}$ \\
GHRR5 & CCATGTAAGCACCTGCTGTCT & 21 & 52 & 60.33 & ---- \\
GHRF6 & TATGTCCGTGTCTCCACCAG & 20 & 55 & 59.26 & $581 \mathrm{bp}$ \\
GHRR6 & GCCACCTGCCCATTAATATC & 20 & 50 & 59.94 & ---- \\
GHRF7 & AGCCTTTAACGGCACACACT & 20 & 50 & 59.80 & $483 \mathrm{bp}$ \\
GHRR7 & TGTCCTATCCAACTTCCCAGA & 21 & 47 & 59.54 & ---- \\
GHRF8 & TTTTGCCTGGTCATTTACTGC & 21 & 42 & 60.12 & $695 \mathrm{bp}$ \\
GHRR8 & CTGTCTGTGTCTGAGCCTTCA & 21 & 52 & 59.19 & ---- \\
GHRF9 & TGGGTGGAATTTATCGAGCTA & 21 & 42 & 59.56 & $945 \mathrm{bp}$ \\
GHRR9 & CAGCCAACTCTTTGCCATTA & 20 & 45 & 58.92 & ---- \\
\hline & & & & &
\end{tabular}


Amplification of GH gene

Amplification of the GH and GHR genes were performed by using a touchdown PCR protocol with annealing temperature range $\left(\mathrm{GH}: 62^{\circ} \mathrm{C}-52^{\circ} \mathrm{C}\right.$ and GHR: $64^{\circ} \mathrm{C}-54^{\circ} \mathrm{C}$ ) on a Bio-Rad thermo cycler. Polymerase chain reaction was carried out in a volume of $25 \mu \mathrm{L}$ using $50 \mathrm{ng} / \mu \mathrm{L}$ genomic DNA, 10x PCR buffer, $2.5 \mathrm{mM}$ dNTPs, $1.5 \mathrm{mM} \mathrm{MgCl}, 0.5 \mathrm{U} \mathrm{Taq}$ Polymerase, and $0.5 \mu \mathrm{L}$ of each primer. Twelve primers were used for the analysis. The thermal cycler was programmed for $5 \mathrm{~min}$ initial denaturation at $95^{\circ} \mathrm{C}$, followed by $30 \mathrm{sec}$ denaturation at $94^{\circ} \mathrm{C}, 30 \mathrm{sec}$ primer annealing at $37^{\circ} \mathrm{C}, 45 \mathrm{sec}$ extension at $72^{\circ} \mathrm{C}$ for 35 cycles and then final extension at $72^{\circ} \mathrm{C}$ for 10 min. PCR products were examined on a gel documentation system after running on the gel. The gel results were analysed against a ladder of $50 \mathrm{bp}$. Sequencing of PCR products was performed using an ABI Prism 3100 Genetic Analyzer (Applied Biosystem Inc. Foster City, CA).

\section{BLAST}

All the sequences were aligned using NCBI online software blast (http://www.ncbi.nlm.nih.gov). SNPs were identified from the aligned sequences. BioEdit translate tool was used to analyse SNPs to look for changes in codons and hence amino acids and protein sequence.

\section{Protein structures}

Protein structure was retrieved from mRNA sequences of genes from the NCBI GenBank database and induced mutations were identified by using BioEdit ver. 7.0 software. Then sequences of mRNA were backtranslated into protein through the Lasergene 7.1 software. For visualising the three-dimensional structure of GH and GHR, we used the SWISS-MODEL server available on the ExPASy website (https://www.expasy.org/) (Bahrami et al., 2012).

\section{RESULTS}

Polymorphisms in the GH gene

In this study we used three primers to flank the GH gene comprised sequence lengths of $287 \mathrm{bp}$ from Exon 1, $161 \mathrm{bp}$ from Exon 2, $165 \mathrm{bp}$ from Exon 3, 156 bp from Exon 4, and 198 bp from Exon 5 of camel GH. Amplified fragments of $187 \mathrm{bp}, 839 \mathrm{bp}$ and $765 \mathrm{bp}$ were obtained. This amplified GH sequence of Marecha breed was compared with GenBank reference sequence of AJ575419.1. Two polymorphic sites (SNPs) were identified by using BLAST, one in the non-coding region (intron 4) at nucleotide position 753 and the other in the coding region (Exon 5) at nucleotide position 1720 (Table II). The mutation in intron 4 was an insertion $(A<G)$ and the mutation in Exon 5 was a transversion $(\mathrm{T}<\mathrm{A})$. The nucleotide substitution at G180 revealed a leucine (L) to histidine $(\mathrm{H})$ polymorphism (L180H) (Fig. 1A).

\section{Polymorphisms in the GHR gene}

Nine primers were used for PCR amplification of the GHR gene's exons with product sizes of 493, 396, 439, $500,439,581,483,695$ and $945 \mathrm{bp}$, the last one amplifying to two exon regions (Fig. 2A). This amplified sequence was then compared with GenBank reference sequence of 105097468. Three polymorphic sites (SNPs) were identified by using BLAST, two in the non-coding region and the other in the coding region as shown in Table III. By sequencing GHR, three SNPs were found in GHR, two from intron and one from Exon 4. SNP A211927 changed the amino acid from methionine to valine, resulting in a codon change from ATG to GTG (Fig. 1B).

Table II. Identified Polymorphisms in genomic region of the growth hormone (GH) and growth hormone receptor (GHR) genes.

\begin{tabular}{|c|c|c|c|c|c|c|c|c|c|}
\hline \multirow{2}{*}{$\begin{array}{l}\text { Genes } \\
\mathrm{GH}\end{array}$} & \multirow{2}{*}{$\begin{array}{l}\text { Nucleo-tide } \\
\text { position* }\end{array}$} & \multirow{2}{*}{$\begin{array}{l}\begin{array}{l}\text { Muta- } \\
\text { tion }\end{array} \\
A>G\end{array}$} & \multirow{2}{*}{$\begin{array}{l}\text { Codon } \\
\text { change }\end{array}$} & \multirow{2}{*}{$\begin{array}{l}\begin{array}{l}\text { Nature of } \\
\text { mutation }\end{array} \\
\text { Intronic }\end{array}$} & \multirow{2}{*}{$\begin{array}{l}\text { Amino acid } \\
\text { substitution }\end{array}$} & \multirow{2}{*}{$\begin{array}{l}\text { Change } \\
\text { type }\end{array}$} & \multicolumn{2}{|c|}{ Allele frequency } & \multirow{2}{*}{$\begin{array}{l}\begin{array}{l}\text { Major allele } \\
\text { frequency }\end{array} \\
0.6585\end{array}$} \\
\hline & & & & & & & A: 0.6585 & G: 0.3415 & \\
\hline & 1720 & $\mathrm{~T}>\mathrm{A}$ & $\begin{array}{l}\text { CTT>- } \\
\text { CAT }\end{array}$ & Exon & $\begin{array}{l}\text { Leucine } \\
>\text { Histidine }\end{array}$ & $\begin{array}{l}\text { Non-syn- } \\
\text { onymous }\end{array}$ & T: 0.6041 & A: 0.3959 & 0.6041 \\
\hline \multirow[t]{3}{*}{ GHR } & 211,834 & $\mathrm{C}>\mathrm{A}$ & - & Intronic & - & - & 0.5099 & 0.4901 & 0.5099 \\
\hline & 211,927 & $\mathrm{~A}>\mathrm{G}$ & $\begin{array}{l}\text { AT- } \\
\mathrm{G}>\mathrm{GTG}\end{array}$ & Exon & Met $>$ Val & $\begin{array}{l}\text { Non-syn- } \\
\text { onymous }\end{array}$ & 0.8096 & 0.1904 & 0.8096 \\
\hline & 108,709 & $\mathrm{C}>\mathrm{A}$ & - & Intronic & - & - & 0.6056 & 0.3944 & 0.6056 \\
\hline
\end{tabular}

Accession Number, GH, AJ575419.1; GHR, 105097468. 


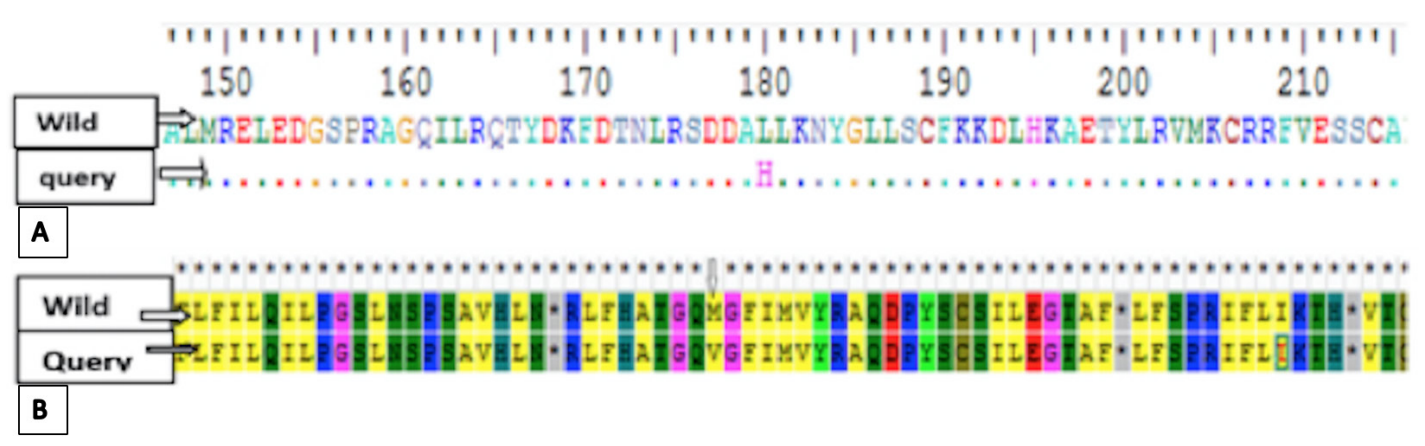

Fig. 1. Growth hormone (GH) gene (A) and growth hormone receptor (GHR) gene (B) of Merecha camel. A shows Leu/His polymorphism while B shows Mathionine/Valine polymorphism.

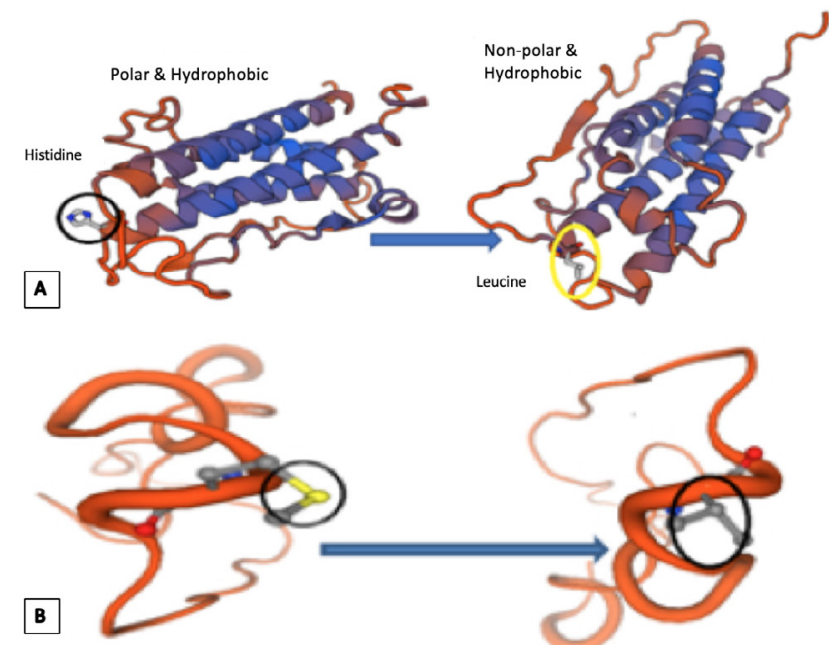

Fig. 2. The change in amino acid in GH protein (A) and GHR protein of Marecha camel. A shows change from Leu to His, while B shows from leucine to histidine.

\section{DISCUSSION}

Genetic improvement has been considered to be an important tool for improving growth and meat production. Detection of genes and polymorphisms associated with quantitative and qualitative traits is an important component of genetic improvement for these economic traits. When the relationship between candidate genes and traits are well recognized, then the genetic potential of breeding animals may be improved. Information about polymorphisms can give vital information about the genomic regions that have been targeted by selection, leading to phenotypic variation.

In the present study, five polymorphic sites were identified in GH and GHR genes of Camelus dromedarius. This study was designed to identify the novel SNPs in these growth-related genes in camels. The finding of polymorphisms in these genes can be used to assess effect of these candidate genes on camel growth and then can be used for marker assisted selection in a genetic improvement program. GHR gene has not been studied before in camel and is novel to the current study. However, SNPs in GH gene have been documented in camel and other species. For example, more than $10 \mathrm{SNPs}$ in the GH gene were detected in cattle (Musa, 2007), and 24 and 19 in Osmanabadi and Sangamneri goat breeds, respectively (Wickramaratne et al., 2009) and seven SNPs in sheep (Bastos et al., 2001) have been reported, while only one SNP was detected in the GH gene of Pakistani (Shah et al., 2006) and Sudanese (Ishag et al., 2010) dromedaries. Several studies found significant associations of $\mathrm{GH}$ polymorphisms with growth and production traits in numerous species. Moradian et al. (2013) observed a significant association of a GH polymorphism with growth traits such as birth weight, weaning weight and six- and nine-month weight in Makooei sheep.

In our study, we identified two SNPs in the GH gene, out of which one SNP was found in the exon and one in the intron region. SNP 1720A was found to be non-synonymous and showed an amino acid change from leucine to histidine. Hediger et al. (1990) studied GH gene polymorphism in the fifth exon at 127 amino acid position and observed that a substitution of cytosine (C) to guanine (G) showed a positive association with growth. Lucy et al. (1993) reported substitution of $\mathrm{C}$ for $\mathrm{G}$ nucleotide at position 2141. This changed the amino acid from leucine to valine with a corresponding increase in growth. Histidine is a key glycoprotein and plays an important role in biological functions such as coagulation, immune response system, fibrinolysis, apoptosis and angiogenesis (Poon et al., 2011). It interacts with various molecules such as plasmin, thrombospondin, vascular endothelial growth factor (VEGF), and the heparin fibroblast growth factor (FGF) family (Poon et al., 2011). Leucine is considered an essential amino acid for protein synthesis and metabolic function. It plays an important role in regulating blood sugar 
level, growth, muscle recovery and stimulating production of GH. Leucine also plays an important role in weight loss as well as muscle building. T1720A substitutions causes a change in amino acids (leu>his) which has influence on the protein structure and biological function of GH.

In GHR, two transversion mutations were detected at positions 211,834 $\mathrm{C}>\mathrm{A}$ and $108,708 \mathrm{C}>\mathrm{A}$ in Introns 4 and 2 respectively, while a transition mutation at position 211,927 $\mathrm{A}>\mathrm{G}$ was found to be non-synonymous: this changes the amino acid from methionine to valine. Simmental bulls with Leu/Leu and Leu/Val genotypes had significantly higher breeding values for a meat trait as compared with the Val/Val genotype (Schlee et al., 1994). In the GH gene of Japanese cattle, animals with methionine showed a high beef marbling score. This association of methionine with high beef marbling scores was only found in Japanese cattle and is considered a characteristic of this cattle breed (Chikuni et al., 1994; Chikuni et al., 1997). Given its importance in other livestock species, this gene can also be used as an indicator for the genetic improvement of growth traits in Camelus dromedarius.

In Balinese cattle, a significant association of GHR with weaning weight and average daily weight gain was observed (Maskur et al., 2014). GHR regulate biological activities of $\mathrm{GH}$ by stimulating signal transduction in target cells. Hale et al. (2000) identified significant associations of GHR with growth, milk production, and carcass traits, and reported a candidate gene associated with growth in Angus cattle. Deepika et al. (2013) found a polymorphism in the exon and intron region of GHR and it has a significant association with milk and growth traits in an indigenous cattle breed. Overall these findings will be helpful to give more insight about potential of these genes in marker assisted selection for growth in a camel breeding program.

\section{CONCLUSION}

Following gene sequencing, five polymorphisms were identified in GH and GHR genes in Marecha camels. This is the first study conducted for molecular characterization of GH and GHR genes in the camel. These identified polymorphisms in marecha camel may be useful markers for selection in a camel breeding program for higher growth and meat production.

\section{Statement of conflict of interest}

The authors declare no conflict of interest.

\section{REFERENCES}

Argetsinger, L.S. and Carter-Su, C., 1996. Mechanism of signaling by growth hormone receptor. Physiol. Rev., 76: 1089-1107. https://doi.org/10.1152/ physrev.1996.76.4.1089

Bahrami, A., Tonelli, M. and Sahu, S., 2012. Integrated protein NMR data collection and assignment by the ADAPT-NMR approach. PLoS One, 7: e33173. https://doi.org/10.1371/journal.pone.0033173

Bastos, E., Cravador, A. and Azevedo, J., 2001. Single strand conformation polymorphism (SSCP) detection in six genes in Portuguese indigenous sheep breed "Churra da Terra Quente". Biotechnol. Agron. Soc. Envir., 5: 7-15.

Blair, J.C. and Savage, M.O., 2002.The GH-IGF-I axis in children with idiopathic short stature. Trends Endrocrinol. Metab., 13: 325-330. https://doi. org/10.1016/S1043-2760(02)00631-8

Chikuni, K., Tabata, T. and Kosugiyama, M., 1994. Polymerase chain reaction assay for detection of sheep and goat meats. Meat Sci., 37: 337-345. https://doi.org/10.1016/0309-1740(94)90051-5

Chikuni, K., Tanabe, R. and Muroya, S., 1997. A simple method for genotyping the bovine growth hormone gene. Anim. Genet,. 28: 230-232. https://doi. org/10.1111/j.1365-2052.1997.00095.x

Deepika, R. and Salar. K., 2013. Polymorphism studies of growth hormone receptor (GHR) gene in Indigenous Grey cattle breeds of India. DHR Intl. J. Biomed. Life Sci., 4: 270-277.

Dybus, A., 2002. Associations of growth hormone (GH) and prolactin (PRL) genes polymorphisms with milk production traits in Polish Black-and-White cattle. Anim. Sci. Pap. Rep., 20: 203-212.

Faye, B., 2015. Role, distribution and perspective of camel breeding in the third millennium economies. Emir. J. Fd Agric., 27: 318-327. https://doi. org/10.9755/ejfa.v27i4.19906

Ge, W., Davis, M. and Hines, H., 2003. Association of single nucleotide polymorphisms in the growth hormone and growth hormone receptor genes with blood serum insulin-like growth factor I concentration and growth traits in Angus cattle. J. Anim. Sci., 81: 641-648. https://doi. org/10.2527/2003.813641x

Gupta, N., Ahlawat, S. and Kumar, D., 2007. Single nucleotide polymorphism in growth hormone gene exon-4 and exon-5 using PCR-SSCP in Black Bengal goats-a prolific meat breed of India. Meat Sci., 76: 658-665. https://doi.org/10.1016/j. meatsci.2007.02.005

Hale, C., Herring, W. and Shibuya, H., 2000. Decreased growth in angus steers with a short TG-microsatellite allele in the P1 promoter of the growth hormone 
receptor gene. J. Anim. Sci., 78: 2099-2104. https:// doi.org/10.2527/2000.7882099x

Hediger, R., Johnson, S.E. and Barendse, W., 1990. Assignment of the growth hormone gene locus to 19q26-qter in cattle and to 11q25-qter in sheep by in situ hybridization. Genomics, 8: 171-174. https:// doi.org/10.1016/0888-7543(90)90241-L

Ishag, I., Reissmann, M. and Peters, K., 2010. Phenotypic and molecular characterization of six Sudanese camel breeds. S. Afr. J. Anim. Sci., 40: 319-326. https://doi.org/10.4314/sajas.v40i4.65244

Lincoln, D., Sinowatz., F. and El-Hifnawi. E., 1995. Evidence of a direct role for growth hormone (GH) in mammary gland proliferation and lactation. Anat. Histol. Embryol., 24: 107-115. https://doi. org/10.1111/j.1439-0264.1995.tb00020.x

Lucy, M.C., Collier, R.J. and Kitchell, M.L.,1993. Immunohistochemical and nucleic acid analysis of somatotropin receptor populations in the bovine ovary. Biol. Reprod., 48: 1219-1227. https://doi. org/10.1095/biolreprod48.6.1219

Maniou. Z., Wallis, O. and Sami, A., 2001. Molecular evolution of growth hormone in Cetartiodactyla. In: 192nd Meeting of the Society for Endocrinology, vol. 2 BioScientifica.

Maskur, R. and Arman, C., 2014. Association of a novel single nucleotide polymorphism in growth hormone receptor gene with production traits in Bali cattle. Ital. J. Anim. Sci., 13: 3461. https://doi. org/10.4081/ijas.2014.3461

Moradian, C., Mohamadi, N. and Sheshdeh, S., 2013. Effects of genetic polymorphismat the growth hormone gene on growth traits in Makooei sheep. Eur. J. exp. Biol., 3: 101-105 https://doi. org/10.1016/j.smallrumres.2012.04.019

Musa, LM., 2007. Characterization and utilization of dairy cattle in Sudan. Verlag Dr. Köster, Berlin.

Poon, I.K., Patel, K.K. and Davis, S., 2011. Histidinerich glycoprotein: the Swiss Army knife of mammalian plasma. Blood, 117: 2093-2101. https:// doi.org/10.1182/blood-2010-09-303842

Repapi, E., Sayers, I. and Wain, L., 2010. Genome-wide association study identifies five loci associated with lung function. Nature Genet., 42: 36.

Sambrook, J. and Russell, D., 2001. Molecular cloning: a laboratory manual III. Cold Spring Laboratory Press, Cold Spring Harbour.

Schlee, P., Graml, R. and Rottmann, O., 1994. Influence of growth-hormone genotypes on breeding values of Simmental bulls. J. Anim. Breed. Genet., 111: 253-256. https://doi.org/10.1111/j.1439-0388.1994. tb00465.x

Shah, M., Qureshi, A. and Reissmann, M., 2006. Sequencing and sequence analysis of myostatin gene in the exon 1 of the camel (Camelus dromedarius). Pakistan Vet. J., 26: 176.

Sodhi, M., Mukesh. M. and Prakash. B., 2007. MspI allelic pattern of bovine growth hormone gene in Indian Zebu cattle (Bos indicus) breeds. Biochem. Genet., 45: 145-153. https://doi.org/10.1007/ s10528-006-9068-4

Sumantran, V., Tsai. M. and Schwartz. J., 1992. Growth hormone induces c-fos and c-jun expression in cells with varying requirements for differentiation. Endocrinology, 130: 2016-2024. https://doi. org/10.1210/endo.130.4.1547725

Wickramaratne, S., Ulmak. B. and Dixit. S., 2009. Use of growth hormone gene plymorphism in selecting osmanabadi and sangamneri goats. Postgraduate Institute of Agriculture, University of Peradeniya: Peradeniya. 